\title{
Permainan Edukatif untuk Meningkatkan Perilaku Pencegahan Demam Berdarah Dengue pada Siswa Pramuka Sekolah Dasar
}

\author{
Meuthya Aulia Dodhy Putri ${ }^{1}$, Bagoes Widjanarko ${ }^{1}$, Martini ${ }^{1}$ \\ ${ }^{1}$ Fakultas Kesehatan Masyarakat Universitas Diponegoro
}

\section{ABSTRACT}

Background: In 2016, the number of Dengue Hemorrhagic Fever (DHF) patients in Southeast Sulawesi has reported as much as 3,433 cases with IR 132.50 per 100,000 populations. The highest case incidence in Kendari reached 1,093 cases (IR = 372.80 per 100,000 population) with the highest cases in the age group 5-14 years reaching $44.9 \%$. This study aims to examine the effect of snake-ladders modification game, as an educative game, for improving DHF prevention in terms of attitudes and behavior of scout students in elementary school.

Method: The study is a quasi-experimental study with pretest-posttest group design by using purposive sampling. The subject is 50 students of Primary School Scouts in the working area of Puskesmas Poasia, Kendari City. Data was collected using a questionnaire and analyzed by Wilcoxon and Mann-Whitney tests.

Results: There is an increase of knowledge ( $p<0,001)$, attitudes $(p<0,001)$, and practices $(p<0,001)$ of primary school students in the prevention of DHF by providing educational game through snake-ladders modification. It recommends that educational game needs to be developed for health education in elementary students.
Correspondence

tinihien65@yahoo.co.id

Article History

Received 10 July 2020

Revised 30 December 2020

Accepted 11 January 2021

Available Online 15 January 2021

Keywords

Health education

Dengue Hemorrhagic Fever

Educative games

Elementary school

Scout

DOI

10.14710/jpki.16.1.31-37

\section{PENDAHULUAN}

Demam Berdarah Dengue (DBD) adalah penyakit menular yang ditularkan oleh virus dengue. Proses penularan dimulai dari gigitan nyamuk Aedes aegypti atau Aedes albopictus yang masuk ke dalam tubuh manusia. Penyakit ini dapat menyerang setiap individu usia berapa pun dan menimbulkan kematian setiap tahun. DBD memiliki kaitan yang sangat besar dengan faktor lingkungan ${ }^{1}$ dan perilaku seseorang ${ }^{2,3}$ dalam kehidupan bermasyarakat. Kejadian DBD banyak ditemukan di daerah tropis dan sub-tropis. Data dari seluruh dunia menunjukkan bahwa Asia menempati urutan pertama terbesar dalam jumlah penderita DBD setiap tahunnya. Sementara itu, terhitung sejak tahun 1968 hingga tahun 2009, World Health Organization (WHO) mencatat negara Indonesia sebagai negara dengan kasus DBD tertinggi di Asia Tenggara 4 .

DBD masih merupakan salah satu masalah kesehatan masyarakat yang utama di Indonesia. Jumlah penderita dan luas daerah penyebarannya semakin bertambah seiring dengan meningkatnya mobilitas dan kepadatan penduduk. Sejak tahun 1968 telah terjadi peningkatan persebaran jumlah provinsi dan kabupaten/kota yang endemis DBD, dari 2 provinsi dan 2 kota, menjadi 32
(97\%) dan 382 (77\%) kabupaten/kota pada tahun 20095. Di tahun 2016, terdapat $463(90,08 \%)$ kabupaten/kota di seluruh Indonesia yang terjangkit DBD. Kementerian Kesehatan RI mencatat jumlah penderita DBD di Indonesia pada bulan Januari-Februari 2016 sebanyak 8.487 orang penderita DBD dengan jumlah kematian 108 orang. Golongan terbanyak yang mengalami DBD di Indonesia pada usia 5-14 tahun mencapai 43,44\% dan usia 15-44 tahun mencapai 33,25\% ${ }^{6}$.

Laporan DBD dari Provinsi Sulawesi Tenggara mencatat dari 17 kabupaten/kota terdapat 12 (70,59\%) kabupaten/kota yang terjangkit DBD pada tahun 2015, dan pada tahun 2016 meningkat menjadi 16 kabupaten/kota $(94,12 \%) .{ }^{(6)}$ Kota Kendari menempati urutan pertama tertinggi angka DBD disusul dengan Kota Baubau, Kabupaten Muna, Konawe Selatan, Kolaka, Konawe, dan Kolaka Utara. Kasus DBD tertinggi terjadi pada tahun 2016 dibandingkan tahun-tahun sebelumnya, dengan jumlah penderita DBD di Sulawesi Tenggara yang dilaporkan sebanyak 3.433 kasus (IR:132,50). Kota Kendari ditetapkan sebagai daerah KLB DBD ${ }^{7}$.

Berdasarkan data dari Dinas Kesehatan Kota Kendari dari tahun 2012 - 2016 diketahui bahwa jumlah kasus semakin meningkat dari tahun ke tahun. Pada tahun 
2012 terdapat 114 kasus, kemudian pada tahun 2013 meningkat menjadi 231 kasus kemudian pada tahun 2014 terdapat 30 kasus kemudian pada tahun 2015 terdapat 78 kasus dan tahun 2016 meningkat menjadi 1.094 kasus (IR: 372,80). Berdasarkan kelompok umur, angka penderita tertinggi pada usia 5-14 tahun sebanyak $46,7 \%$ pada tahun 2013, kemudian menurun menjadi $40 \%$ pada tahun 2014 , tahun 2015 meningkat menjadi 44.9\% dan pada tahun 2016 semakin meningkat menjadi $46,8 \%$, serta disusul kelompok umur $>15$ tahun $(35,4 \%)$ dan $<5$ tahun $(17,82 \%)^{7}$. Kasus DBD tertinggi berada di Wilayah Kerja Puskesmas Poasia dengan 148 kasus pada tahun 2016. Berdasarkan data dari Puskesmas Poasia, terdapat 54\% dari seluruh kelompok umur yang menderita DBD berada di usia sekolah yaitu 5-14 tahun. Secara spesifik, 37,5\% di antaranya berusia 6-12 tahun yang termasuk dalam kategori usia sekolah dasar ${ }^{8}$.

Perubahan iklim yang berpengaruh terhadap kehidupan vektor menjadi salah satu penyebab meningkatnya kasus DBD. Faktor perilaku dan partisipasi masyarakat yang masih kurang dalam kegiatan Pemberantasan Sarang Nyamuk (PSN) serta faktor pertambahan jumlah penduduk dan faktor peningkatan mobilitas penduduk yang sejalan dengan semakin membaiknya sarana transportasi turut menyebabkan penyebaran virus DBD semakin mudah dan semakin luas ${ }^{2,3,5}$.

Tingginya kasus DBD pada anak terutama pada usia sekolah menjadikan pendidikan kesehatan untuk kelompok ini harus selalu diupayakan dan berkesinambunga. Pendidikan kesehatan pada anak usia sekolah dasar perlu diupayakan untuk meningkatkan pemahaman tentang DBD dan pencegahannya. Intervensi pendidikan kesehatan berbasis sekolah merupakan alat yang efektif untuk menurunkan angka DBD dibandingkan intervensi lainnya 9 . Anak-anak mempunyai rasa ingin tahu yang tinggi serta keinginan yang kuat dalam mempelajari hal-hal baru yang ditemuinya. Mereka dapat berperan sebagai agen perubahan yang efektif sehingga mampu membawa perubahan perilaku sehat di lingkungannya ${ }^{10}$.

Metode edukasi yang tepat untuk anak usia sekolah adalah melalui permainan edukatif seperti permainan ular tangga. Edukasi melalui permainan di sekolah dapat memanfaatkan kegiatan ekstrakulikuler yaitu pramuka. Pramuka merupakan wadah aktivitas anak sekolah yang mempunyai kapasitas tinggi dalam membentuk kepribadian bertanggung jawab dan menumbuhkan rasa kebersamaan dan jiwa sosial yang tinggi. Aktivitas siswa pramuka dapat dipantau dan dievaluasi langsung oleh pembina pramuka sehingga keberlanjutan edukasi dapat terjamin dan memberikan manfaat secara langsung.

Penelitian ini bertujuan untuk menganalisis pengaruh pendidikan kesehatan melalui permainan edukatif terhadap peningkatan pengetahuan, sikap dan praktik siswa pramuka sekolah dasar dalam upaya pencegahan DBD di wilayah kerja Puskesmas Poasia Kota Kendari.

\section{METODE}

Penelitian ini menggunakan metode Quasi Eksperimental dengan rancangan non-equivalent control group design. Intervensi penelitian ini berupa permainan edukatif tentang penanggulangan DBD dengan memodifikasi permainan ular tangga. Dua sekolah dasar di wilayah kerja Puskesmas Poasia yang berbeda lokasi dijadikan kelompok kontrol dan kelompok intervensi. Subyek penelitian yaitu siswa sekolah dasar yang aktif di kegiatan pramuka, dengan jumlah subyek masing-masing sebanyak 25 siswa pramuka yang sedang tidak menjalani persiapan ujian akhir nasional.

Materi pendidikan kesehatan yang dituangkan dalam permainan ular tangga berisi definisi, penyebab, cara penularan dan pencegahan DBD. Informasi pada permainan ular tangga berupa pesan gambar dan tulisan. Permainan ular tangga dicetak dalam MMT ukuran 4 x 5 meter. Terdapat 5 kelompok yang beranggotakan masing-masing 5 siswa. Pemilihan kelompok yang bermain terlebih dahulu ditentukan dengan melempar dadu. Permainan ular tangga dilakukan satu kali pada setiap kelompok dengan lama bermain 1-2 jam. Ketika anggota siswa bermain, maka siswa lainnya menunggu giliran. Setiap anggota diwajibkan mengikuti permainan sampai selesai.

Pengukuran variabel pengetahuan, sikap dan praktik (PSP) dilakukan sebelum intervensi dan setelah intervensi. Pengukuran PSP pada kelompok kontrol dilakukan dalam periode yang sama dan diukur 2 kali. Pengukuran menggunakan kuesioner yang telah diuji coba dan diuji validitas. Hasil pengukuran dianalisis dengan uji statistik Wilcoxon dan Mann-Whitney pada tingkat kepercayaan $95 \%$.

Penelitian ini telah mendapatkan kelayakan etik oleh Komisi Etik Penelitian Fakultas Kesehatan Masyarakat Universitas Diponegoro No. 075/EC/FKM/2018.

\section{HASIL DAN PEMBAHASAN}

Tabel 1 menjelaskan bahwa karakteristik responden berdasarkan umur antara kelompok intervensi dan kontrol menunjukkan hasil bahwa jenis kelamin responden pada kelompok intervensi lebih banyak perempuan (60\%) dan kelompok kontrol paling banyak berjenis kelamin laki-laki $(64 \%)$. Secara statistik, perbandingan persentase berdasarkan jenis kelamin pada kedua kelompok adalah sebanding ( $p$ value $=0,089$ ) atau tidak terdapat perbedaan antara kedua kelompok. Demikian juga dengan sebaran usia responden pada kelompok intervensi dan kontrol ( $\mathrm{p}$ value $=0,531$ ), sehingga dapat diinterpretasikan bahwa karakter responden pada kedua kelompok tersebut setara.

Tabel 2 menunjukkan bahwa nilai pre-test 
terendah yaitu ada pada pernyataan nyamuk DBD senang beraktivitas pada malam hari. Sedangkan nilai pre-test tertinggi ada pada pernyataan bak mandi dapat menjadi tempat hidup nyamuk. Terjadi peningkatan pengetahuan pada kelompok intervensi. Pengetahuan mengenai pencegahan DBD dilihat melalui 15 indikator.

Sikap responden mengenai pencegahan serta pengendalian DBD dilihat melalui 12 indikator pada tabel 3. Hasil penelitian menunjukkan bahwa terjadi peningkatan nilai post-test variabel sikap responden pada kelompok intervensi. Nilai post-test variabel sikap pada kelompok kontrol menunjukkan terjadi penurunan di beberapa indikator sikap.

Tabel 4 menunjukkan nilai pre-test dan post-test responden pada variabel praktik pencegahan serta pengendalian DBD. Nilai post-test kelompok intervensi yang paling tinggi adalah 96 ada pada 3 indikator praktik yaitu memberitahu orang tua jika di bak mandi ada jentik, membersihkan rumah dari kontainer yang ada jentik, serta menyemprot rumah dengan anti nyamuk setiap hari. Sedangkan pada kelompok kontrol nilai post-test tertinggi adalah 48 yaitu pada indikator membuang sampah pada tempatnya.

Tabel 1. Karakteristik responden

\begin{tabular}{|c|c|c|c|c|c|c|c|}
\hline \multirow[t]{3}{*}{ Karakteristik } & \multicolumn{4}{|c|}{ Kelompok } & \multirow{2}{*}{\multicolumn{2}{|c|}{ Jumlah }} & \multirow[t]{3}{*}{$p$ value } \\
\hline & \multicolumn{2}{|c|}{ Intervensi } & \multicolumn{2}{|c|}{ Kontrol } & & & \\
\hline & f & $\%$ & f & $\%$ & f & $\%$ & \\
\hline \multicolumn{8}{|l|}{ Jenis kelamin } \\
\hline Laki-laki & 10 & 40 & 16 & 64 & 26 & 52 & \multirow[t]{2}{*}{0,089} \\
\hline Perempuan & 15 & 60 & 9 & 36 & 24 & 48 & \\
\hline \multicolumn{8}{|l|}{ Usia (tahun) } \\
\hline 10 & 10 & 40 & 8 & 32 & 18 & 36 & \multirow{3}{*}{0,531} \\
\hline 11 & 12 & 48 & 11 & 44 & 23 & 46 & \\
\hline 12 & 3 & 12 & 6 & 24 & 9 & 18 & \\
\hline
\end{tabular}

Tabel 2. Pengetahuan pencegahan DBD pada kelompok intervensi dan kontrol

\begin{tabular}{|c|c|c|c|c|c|}
\hline \multirow[t]{2}{*}{ Item Pertanyaan } & \multicolumn{3}{|c|}{$\begin{array}{c}\text { Intervensi } \\
\text { (\% skor benar) }\end{array}$} & \multicolumn{2}{|c|}{$\begin{array}{c}\text { Kontrol } \\
\text { (\% skor benar) }\end{array}$} \\
\hline & Pre & Post 1 & Post 2 & Pre & Post 1 \\
\hline Penyebab DBD & 44 & 76 & 80 & 56 & 52 \\
\hline Ciri-ciri vektor DBD & 48 & 76 & 84 & 52 & 56 \\
\hline Tindakan jika teman sakit DBD & 40 & 72 & 76 & 56 & 56 \\
\hline Memakai baju dan celana lengan panjang untuk Pencegahan DBD & 52 & 76 & 80 & 40 & 44 \\
\hline Membuang sampah sembarangan dapat menjadi sarang nyamuk & 40 & 84 & 88 & 60 & 56 \\
\hline Menggantung baju dapat menjadi sarang nyamuk & 52 & 80 & 88 & 52 & 56 \\
\hline Selokan dapat menjadi sarang nyamuk penular DBD & 36 & 64 & 84 & 36 & 48 \\
\hline Nyamuk DBD senang beraktivitas di malam hari & 36 & 76 & 80 & 48 & 44 \\
\hline Nyamuk penular DBD adalah Aedes Aegypti & 44 & 60 & 84 & 48 & 56 \\
\hline Bak mandi dapat menjadi tempat hidup jentik nyamuk & 68 & 84 & 92 & 60 & 56 \\
\hline Penggunaan peralatan makan/minum bersama dapat menularkan DBD & 52 & 60 & 80 & 56 & 56 \\
\hline Nyamuk penular DBD senang beraktivitas pada pukul 11.00-12.00 & 52 & 60 & 68 & 44 & 48 \\
\hline Nyamuk penular DBD senang beristrahat dekat lampu yang terang & 56 & 68 & 80 & 48 & 48 \\
\hline Nyamuk DBD dapat berkembang biak di air bersih & 48 & 80 & 84 & 56 & 52 \\
\hline Batuk dapat menularkan penyakit DBD & 52 & 80 & 84 & 56 & 56 \\
\hline
\end{tabular}


Tabel 3. Sikap pencegahan DBD pada kelompok intervensi dan kontrol

\begin{tabular}{|c|c|c|c|c|c|c|}
\hline \multirow[t]{2}{*}{ No. } & \multirow[t]{2}{*}{ Item Pertanyaan } & \multicolumn{3}{|c|}{$\begin{array}{l}\text { Intervensi } \\
(\% \text { Setuju })\end{array}$} & \multicolumn{2}{|c|}{$\begin{array}{l}\text { Kontrol } \\
(\% \text { Setuju })\end{array}$} \\
\hline & & Pre & Post 1 & Post 2 & Pre & Post 1 \\
\hline 1. & Akan membuang airnya jika menemukan kaleng ada airnya & 68 & 84 & 92 & 60 & 52 \\
\hline 2. & Menjauhi orang yang sakit DBD karena dapat tertular & 24 & 60 & 72 & 36 & 48 \\
\hline 3. & Tidak berteman dengan penderita DBD & 32 & 80 & 88 & 40 & 60 \\
\hline 4. & $\begin{array}{l}\text { Lotion anti nyamuk perlu digunakan di sekolah supaya tidak digigit } \\
\text { nyamuk }\end{array}$ & 52 & 64 & 80 & 40 & 44 \\
\hline 5. & Kebersihan rumah dari sarang nyamuk adalah pekerjaan orang tua & 24 & 68 & 76 & 32 & 60 \\
\hline 6. & Mengajak teman untuk rajin membersihkan rumah dan sekolah & 40 & 48 & 84 & 28 & 44 \\
\hline 7. & Kebersihan sekolah adalah tugas dari pihak sekolah & 20 & 72 & 80 & 36 & 40 \\
\hline 8. & $\begin{array}{l}\text { Membuang sampah pada tempatnya baik di sekolah maupun di } \\
\text { rumah }\end{array}$ & 40 & 64 & 68 & 48 & 48 \\
\hline 9. & Kebersihan diri dapat mencegah DBD & 36 & 72 & 84 & 32 & 32 \\
\hline 10. & Mencegah DBD hanya tugas orang tua & 20 & 80 & 88 & 44 & 48 \\
\hline 11. & $\begin{array}{l}\text { Membuang sampah sembarangan oleh orang lain adalah tanggung } \\
\text { jawab mereka }\end{array}$ & 24 & 76 & 84 & 64 & 58 \\
\hline 12. & Ilmu baru tentang DBD tidak perlu diberitahukan ke teman lain & 32 & 68 & 72 & 40 & 40 \\
\hline
\end{tabular}

Tabel 4. Praktik pencegahan DBD pada kelompok intervensi dan kontrol

\begin{tabular}{|c|c|c|c|c|c|c|}
\hline \multirow[t]{2}{*}{ No. } & \multirow[t]{2}{*}{ Item Pertanyaan } & \multicolumn{3}{|c|}{$\begin{array}{c}\text { Intervensi } \\
\text { (\% skor benar) }\end{array}$} & \multicolumn{2}{|c|}{$\begin{array}{c}\text { Kontrol } \\
\text { (\% skor benar) }\end{array}$} \\
\hline & & Pre & Post 1 & Post 2 & Pre & Post 1 \\
\hline 1. & Penyebab DBD & 44 & 76 & 80 & 56 & 52 \\
\hline 2. & Ciri-ciri vektor DBD & 48 & 76 & 84 & 52 & 56 \\
\hline 3. & Tindakan jika teman sakit DBD & 40 & 72 & 76 & 56 & 56 \\
\hline 4. & Memakai baju dan celana lengan panjang untuk pencegahan DBD & 52 & 76 & 80 & 40 & 44 \\
\hline 5. & Membuang sampah sembarangan dapat menjadi sarang nyamuk & 40 & 84 & 88 & 60 & 56 \\
\hline 6. & Menggantung baju dapat menjadi sarang nyamuk & 52 & 80 & 88 & 52 & 56 \\
\hline 7. & Selokan dapat menjadi sarang nyamuk penular DBD & 36 & 64 & 84 & 36 & 48 \\
\hline 8. & Nyamuk DBD senang beraktivitas di malam hari & 36 & 76 & 80 & 48 & 44 \\
\hline 9. & Nyamuk penular DBD adalah Aedes Aegypti & 44 & 60 & 84 & 48 & 56 \\
\hline 10. & Bak mandi dapat menjadi tempat hidup jentik nyamuk & 68 & 84 & 92 & 60 & 56 \\
\hline 11. & Penggunaan peralatan makan/minum bersama dapat menularkan DBD & 52 & 60 & 80 & 56 & 56 \\
\hline 12. & Nyamuk penular DBD senang beraktivitas pada pukul 11.00-12.00 & 52 & 60 & 68 & 44 & 48 \\
\hline 13. & Nyamuk penular DBD senang beristrahat dekat lampu yang terang & 56 & 68 & 80 & 48 & 48 \\
\hline 14. & $\begin{array}{l}\text { Nyamuk DBD dapat berkembang biak di tempat penampungan air } \\
\text { yang bersih }\end{array}$ & 48 & 80 & 84 & 56 & 52 \\
\hline 15. & Batuk dapat menularkan penyakit DBD & 52 & 80 & 84 & 56 & 56 \\
\hline
\end{tabular}

Tabel 5 menunjukkan nilai median pada variabel pengetahuan pada kelompok intervensi untuk pre-test adalah 40, sedangkan untuk post-test 1 sebesar 73,3. Berdasarkan hasil tersebut, dapat terlihat bahwa pada posttest 1 terjadi peningkatan pengetahuan dibanding sebelum intervensi. Dari hasil uji tersebut diperoleh hasil bahwa terdapat perbedaan yang bermakna terhadap tingkat pengetahuan antara pre-test dan post-test 1 . Peningkatan pengetahuan terukur juga pada post-test 2. Hasil uji statistik untuk pengetahuan pada kelompok kontrol untuk setara pre-test sebesar 46,6 dan post-test sebesar 53,3. Skor tersebut secara statistik tidak bermakna ( $\mathrm{p}$ value $=0,874$ ).

Baik skor sikap dan praktik pada kedua kelompok didapatkan hasil yang sama, yaitu secara statistik bermakna antara sebelum intervensi dan setelah intervensi. Skor sikap meningkat 16,6 setelah intervensi $(\mathrm{p}<0,0001)$ dan meningkat lagi sebesar 4 skor. Skor praktik jauh meningkat setelah intervensi sebesar 40 skor $(\mathrm{p}<0,0001)$. 
Tabel 5. Perilaku pengendalian DBD pada kelompok intervensi dan kontrol dengan uji Wilcoxon

\begin{tabular}{|c|c|c|c|c|}
\hline \multirow{2}{*}{ Variabel } & \multicolumn{3}{|c|}{ Median } & \multirow{2}{*}{$p$ value } \\
\hline & Pre & Post 1 & Post 2 & \\
\hline \multicolumn{5}{|l|}{ Pengetahuan } \\
\hline Intervensi & 40 & 73,3 & 80 & $0,000^{*}$ \\
\hline Kontrol & 46,6 & 53,3 & & 0,874 \\
\hline \multicolumn{5}{|l|}{ Sikap } \\
\hline Intervensi & 66,7 & 83,3 & 87,5 & $0,001 *$ \\
\hline Kontrol & 70,8 & 66,7 & & 0,426 \\
\hline \multicolumn{5}{|l|}{ Praktik } \\
\hline Intervensi & 40 & 80 & 86,7 & $0,000^{*}$ \\
\hline Kontrol & 26,7 & 40 & & 0,052 \\
\hline
\end{tabular}

Keterangan: Tanda * menunjukkan siginifikan pada $\alpha=0,05$ dengan uji Wilcoxon antara pre-test dan post-test pengukuran ke satu (post-test 1 )

Tabel 6. Perilaku pengendalian DBD pada kelompok intervensi dan kontrol dengan uji Mann Whitney

\begin{tabular}{lcc}
\hline Variabel & Median & P value \\
\hline $\begin{array}{l}\text { Pengetahuan } \\
\text { Intervensi }\end{array}$ & 80 & $<0,0001^{*}$ \\
Kontrol & 53,3 & \\
\hline Sikap & & \\
$\quad$ Intervensi & 87,5 & $<0,0001^{*}$ \\
$\quad$ Kontrol & 66,7 & \\
\hline Praktik & & \\
$\quad$ Intervensi & 83,3 & $<0,0001^{*}$ \\
Kontrol & 40 &
\end{tabular}

Keterangan: Tanda * menunjukkan siginifikan pada $\alpha=0,05$ dengan uji Mann Whitney antara post-test pada intervensi dan kontrol.

Perbedaan pengetahuan, sikap dan praktik antara kelompok intervensi dan kontrol yang diukur setelah periode tertentu (post-test pertama) secara statistik bermakna. Median skor pengetahuan stelah intervensi sebesar 80 dibandingkan dengan kontrol 53,3 ( $\mathrm{p}<0,0001)$, median skor sikap 87,5 ( $\mathrm{p}<0,0001)$ dibanding kelompok kontrol sebesar 66,7. Median skor untuk praktik dua kali lipat dibandingkan kontrol $(\mathrm{p}<0,0001)$.

Keterlibatan siswa SD dalam pengendalian DBD sangat dibutuhkan mengingat angka insiden DBD pada anak sekolah cukup tinggi ${ }^{11}$. Metode yang diberikan ini memiliki efektivitas yang baik terutama diberikan pada kelompok sasaran siswa sekolah dasar. Diharapkan metode ini memiliki kontribusi dalam penanggulangan DBD di sekolah. Penelitian ini berfokus pada pendidikan kesehatan melalui permainan edukatif.

Intervensi permainan edukatif yang berbentuk ular tangga yang berisikan pesan-pesan kesehatan mengenai DBD dan pencegahan diberikan pada kelompok intervensi.
Peningkatan pengetahuan, sikap dan praktik (PSP) siswa SD yang aktif di pramuka meningkat dua kali dibandingkan sebelum intervensi, peningkatan PSP berlangsung sampai pada pengamatan kedua (post-test 2), namun tidak terlalu signifikan. Pada kelompok siswa pramuka SD kontrol yang tidak diberikan intervensi yang berupa permainan edukatif mempunyai skor median PSP yang tetap sama. Hal ini menunjukkan bahwa intervensi permainan edukatif dapat meningkatkan PSP siswa pramuka SD. Pemberian intervensi dilakukan setiap minggu terutama pada saat kegiatan pramuka diadakan di sekolah, dan berlangsung sampai 1 bulan. Dua kelompok sekolah yang digunakan adalah sekolah yang berbeda sehingga kontaminasi antar subyek penelitian dapat diminimalkan. Karakteristik terkait jenis kelamin dan umur antara kedua kelompok sebanding. Usia siswa pada kelompok intervensi maupun kelompok kontrol tidak begitu jauh berbeda dalam segi jumlah dan juga batas usia terbawah yaitu 10 tahun dan batas tertinggi 12 tahun. Berdasarkan jenis kelamin, pada kelompok intervensi responden perempuan merupakan responden terbanyak, sedangkan pada kelompok kontrol responden laki-laki yang memiliki jumlah terbanyak, namun secara statistik tidak bermakna atau setara.

Permainan edukatif merupakan salah satu metode yang menarik dan efektif dalam meningkatkan PSP anak usia sekolah dasar. Permainan edukatif memuat pesan sederhana dan mudah dipahami. Metode ini dapat membuat siswa aktif dalam bermain sekaligus belajar sehingga memudahkan menyerap pengetahuan tentang DBD dan kemudian mampu menerapkannya dalam kehidupan siswa sehari-hari. Permainan memiliki manfaat dan berdampak positif pada perkembangan emosional dan intelektual anak itu sendiri ${ }^{12}$.

Permainan edukatif berupa ular tangga juga dilakukan oleh beberapa peneliti dengan menampilkan pesan yang berbeda sesuai dengan tujuan penelitian. Penelitian yang dilakukan Handayani dalam meningkatkan pengetahuan tentang manfaat buah dan sayur pada anak anak ${ }^{13}$, dan Zamzami untuk pencegahan penyakit $\mathrm{PES}^{14}$ menunjukkan hasil bahwa permainan ular tangga merupakan media yang efektif untuk menyampaikan berbagai pesan kesehatan pada anak usia sekolah dasar. Keberhasilan suatu pendidikan dipengaruhi oleh strategi yang digunakan, metode serta alat bantu yang dapat menunjang keberhasilan kegiatan pendidikan tersebut ${ }^{12}$. Penyuluhan kesehatan sangat erat kaitannya dengan hal-hal yang dapat mengubah perilaku dan membantu mendapatkan tujuan yang diharapkan ${ }^{13}$.

Program kesehatan yang dilakukan oleh dinas kesehatan melalui puskesmas sudah berjalan, terutama dalam melaksanakan Program Pemerintah yaitu GERMAS (Gerakan Masyarakat Hidup Sehat), seperti DBD, diare dan PHBS (Perilaku Hidup Bersih dan Sehat). Germas untuk 
anak sekolah diberikan dengan metode penyuluhan klasik, meskipun dalam metode penyuluhan juga digunakan alat bantu media leaflet dan poster. Media leaflet dan poster bentuknya adalah pasif, sedangkan pada kelompok usia sekolah dasar lebih menyukai suasana interaktif seperti yang dapat diperoleh melalui bermain. Permainan edukatif perlu dikembangkan dan diberikan untuk memberikan suasana yang berbeda dan anak tidak mudah bosan ${ }^{15}$.

Siswa sekolah dasar yang dipilih dalam penelitian ini adalah siswa yang aktif mengikuti kegiatan pramuka di sekolahnya. Hal ini dikarenakan pramuka merupakan wadah bagi siswa sekolah untuk kreatif, menolong sesama dan berjiwa sosial yang tinggi, sehingga ketika anak mendapatan pengetahuan dan inovasi yang baru maka mereka dapat menjadi penggerak bagi teman sebaya di lingkungan sekolahnya. Berdasarkan hasil ini, maka puskesmas dapat memasukkan program-program kesehatan anak sekolah melalui wadah kepramukaan ${ }^{16}$.

Bermain sebuah permainan memiliki manfaat pada anak dan memiliki dampak positif pada perkembangan emosional dan intelektual anak itu sendiri, sehingga mereka dapat melatih kemampuan dalam pemecahan masalah pada lingkungannya yang dipengaruhi oleh kondisi dan situasi anak dan disesuaikan dengan kemampuannya. Bermain dapat memberikan kebahagiaan, meningkatkan harga diri anak, dan memberi kesempatan anak untuk dapat belajar bagaimana dalam mengelola perasaannya ${ }^{17}$.

\section{SIMPULAN}

Pendidikan kesehatan melalui permainan edukatif yang berupa permainan ular tangga dapat meningkatkan pengetahuan, sikap dan praktik (PSP) siswa pramuka di sekolah dasar dalam pencegahan DBD di wilayah kerja Puskesmas Poasia Kota Kendari. Permainan edukatif memberikan suasana yang berbeda dan anak tidak mudah bosan sehingga dapat digunakan sebagai sarana menerapkan Germas pada usia anak sekolah.

\section{KEPUSTAKAAN}

1. Anwar A, Ariati J. Model Prediksi Kejadian Demam Berdarah Dengue (Dbd) Berdasarkan Faktor Iklim di Kota Bogor, Jawa Barat. Bul. Penelit. Kesehat. 2014. Des; 42 (4): 249-256

2. Yunita J, Mitra, Susmaneli H. Pengaruh Perilaku Masyarakat Dan Kondisi Lingkungan Terhadap Kejadian Demam Berdarah Dengue. Jurnal Kesehatan Komunitas. 2012. Mei; 1 (4) : 193-198

3. Lestari ND, Martini M, Saraswati LD, Hestiningsih Retno. Perbedaan Perilaku Pencegahan DBD Dan Kepadatan Vektor Pada Kelompok Post Dan Tanpa Intervensi Komunikasi Perubahan Perilaku (KPP). Jurnal Kesehatan Masyarakat. 2017. Okt; 5 (4) : 431-443
4. WHO. Comprehensive Guidelines for Prevention and Control of Dengue and Dengue Haemorrhagic Fever (Revised and expanded edition). India : New Dehli. 2011

5. Pusat Data dan Surveilans Epidemiologi Kemenkes RI. Buletin Jendela Epidemiologi Demam Berdarah Dengue. 2010. Agust ; $1: 1-14$

6. Kemenkes RI. Profil Kesehatan Indonesia Tahun 2017. Jakarta : Kemenkes RI. 2018.

7. Dinas Kesehatan Provinsi Sulawesi Tenggara. Profil Kesehatan Sulawesi Tenggara Tahun 2016. Kendari : Dinkes Provinsi Sulawesi Tenggara. 2017

8. Dinas Kesehatan Kota Kendari. Laporan Kasus DBD di Kota Kendari Tahun 2016. Kendari : Dinke Kota Kedari. 2017.

9. Deepthi R, Naresh Kumar SJ, Prasanna Kamath BT, Rajeshwari H. Participatory school health education on vector-borne diseases: Engaging children as change agents. Int J Health Promot Educ. 2014. 52 (issue 2) : 68-77.

10. Alok S, Nessa S, Ahil SB. School Training Strategies for Prevention and Control of Dengue. Indian J Community Med. 2020. Jan-Mar; 45 (1) : 106-107.

11. Sari P, Martini M, Ginanjar P. Hubungan Kepadatan Jentik Aedes Sp Dan Praktik Psn Dengan Kejadian Dbd Di Sekolah Tingkat Dasar Di Kota Semarang. Jurnal Kesehatan Masyarakat, Volume 1, Nomor 2. 2012. 413 $-422$

12. Putranto AY, Fitriangga A, Liana DF. Promosi Kesehatan dengan Metode Peer Education terhadap Pengetahuan tentang Demam Berdarah Dengue (DBD) Siswa SMA. Jurnal Vokasi Kesehatan .2015. Maret; 1 (2): $39-44$

13. Handayani I, Lubis Z, Aritonang E Y. Pengaruh Penyuluhan dengan Media Permainan Ular Tangga terhadap Pengetahuan tentang Buah dan Sayur pada Siswa MTs-S Al- Manar Kecamatan Hamparan Perak. Jumantik. 2018; 3 (1): 115-123

14. Zamzami M, Astuti D, Werdani K E. Metode Ular Tangga Dalam Meningkatkan Pengetahuan Dan Sikap Siswa Tentang Pencegahan Penyakit PES. Jurnal Kesehatan Masyarakat Andalas. 2016; 11 (1) : 55-63

15. Cahyaningtyastuti, Maria Pratami, Birmanti Setia Utami, and Jasson Prestiliano. Perancangan Board Game sebagai Media Pembelajaran tentang Pentingnya Merawat Gigi bagi Anak Usia Sekolah Dasar. Citradirga-Jurnal Desain Komunikasi Visual dan Intermedia 2.01. $2020:$ 41-52.

16. Pratiwi, Septiana Intan, et al. Pengaruh ekstrakurikuler pramuka terhadap karakter disiplin siswa SD. Edukatif: Jurnal Ilmu Pendidikan 2.1 .2020 : 62-70. 
17. Pickett G, Hanlon JJ. Kesehatan Masyarakat: Administrasi dan Praktik. Alih Bahasa : Ali Gufron Mukti ; 9th ed. Jakarta: EGC. 2009. 